\title{
The effect of bank-specific factors and unstable macroeconomic environment on bank efficiency: evidence from FCC
}

\author{
Salem Mohammad Abdelaziz Salem ${ }^{1, *}$, Nora Azureen Abdul Rahman ${ }^{2}$ \\ ${ }^{1}$ Faculty of Management and Finance, Palestine Technical University, Tulkarem, Palestine \\ ${ }^{2}$ School of Economics, Finance and Banking, Universiti Utara Malaysia, Kedah, Malaysia
}

\section{A R T I C L E I N F O}

\section{Article history:}

Received 19 July 2016

Received in revised form

2 September 2016

Accepted 26 September 2016

\section{Keywords:}

Bank-specific

Macroeconomic

Efficiency

FCC

\begin{abstract}
A B S T R A C T
The banking industry in the area of Fertile Crescent Countries (FCC) was faced by instability in their political and economic conditions in the last decade, especially during the Arab spring revolutions. The current study investigates empirically the efficiency of banking sector in the troublous areas in developing countries such as FCC. The efficiency estimates of individual banks are evaluated by employing the multiple regression models. This paper examines the effect of a selected bank-specific factors, and unstable macroeconomic conditions on bank efficiency in a selected FCC banks for 10 - year's period 2005-2014. The unbalanced panel data used in this study is derived from Bank Scope data network. The empirical findings are almost consistent with the expected results. Bank deposits and bank size have influence on bank efficiency. Economic conditions found with no effect on efficiency. It was found that liquidity of a bank does not influence bank efficiency, but bank diversification is related with efficiency in FCC.
\end{abstract}

(C) 2016 The Authors. Published by IASE. This is an open access article under the CC BY-NC-ND license (http://creativecommons.org/licenses/by-nc-nd/4.0/).

\section{Introduction}

Banks are important participants of financial markets and play an essential role in the financial stability and economic development, especially in developing countries; the unstable political and macroeconomic environment having a remarkable effect on the efficiency of banking sector in the unstable area of Fertile Crescent Countries (FCC). Sufian (2012) indicated that the performance of banks will be based on their efficiency and profitability. The performance of FCC banks was below world standard. The annual reports of the Association of Banks in FCC, namely: Palestine, Jordan, and Lebanon showed that the average return on assets (ROA) for FCC banks is 0.66 , where the world standard of ROA is $1.8 \%$ according to (GarcíaHerrero et al., 2009). Moreover, the world bank reports (The World Bank, Available at: https://research.stlouisfed.org/fred2/search?st=RO $\mathrm{A}+\mathrm{in}+\mathrm{GCC}+$ counries) during the last five years 2010 2014 showed that the average ROA to GDP ratio in FCC region is 0.23 and the average ROE to GDP is

\footnotetext{
* Corresponding Author.

Email Address: smasalem@gmail.com (S. M. A. Salem)

https://doi.org/10.21833/ijaas.2016.09.014

2313-626X/@ 2016 The Authors. Published by IASE

This is an open access article under the CC BY-NC-ND license

(http://creativecommons.org/licenses/by-nc-nd/4.0/)
}

2.13 percent as shown in Table 1. While, the average ROA to GDP and ROE to GDP in GCC countries is .36 and 2.77 respectively in the same period 2010-2014. Thus, ROA to GDP ratio in GCC countries exceeds their counter parts in FCC countries by 56.5 percent; also the ROE to GDP ratio in GCC exceeds the ratio of ROE to GDP in FCC by 30.05 percent. Therefore, the efficiency of the banking sector is declining in the area of Fertile Crescent countries (FCC) in the last five years (2010-2014) compared to their counterparts in other neighboring GCC countries.

By employing an exclusive data set of selected banks operating in FCC region during the period of 2005-2014, this study contributes to the existing literature by providing new empirical evidence on the impact of the unstable bank-specific and macroeconomic factors on the efficiency of banking sector in a troublous FCC area. Since, banks are the most dominant financial institutions in FCC area due to the peoples' lower standard of living, and the high dependency on financial sector by both individuals and governments in FCC because of their continuous deficit in their fiscal budgets. The research questions addressed in this paper are: Does bank-specific factors affects the efficiency of a bank?, What is the effect of the unstable macroeconomic factors on bank efficiency? These findings may provide some important visions to both policy makers and bank managers in the unstable area of FCC. 


\section{Literature review}

The debate on bank efficiency is tremendous in banking literature, but few studies were done on developing countries such as FCC. Previous studies discussed the impact of different aspects such as the role of bank ownership, bank size, NPLs, and bank capital on banking efficiency. However, Ataullah and
Le (2006) studied the effect of fiscal reforms, financial reforms, and private investment liberalization on bank efficiency in Indian banking sector. They found that the improvement in foreign bank's efficiency was due to economic reforms, and there is a negative relationship between fiscal deficits and bank efficiency.

Table 1: ROA and ROE to GDP ratios in FCC Banks during the last 5 years (2010-2014)

\begin{tabular}{|c|c|c|c|c|c|c|c|c|c|c|}
\hline FCC & & & & & & GDP & & & & \\
\hline Country Name & 2010 & 2011 & 2012 & 2013 & 2014 & $\begin{array}{c}\text { Mean } \\
\text { GDP }\end{array}$ & $\begin{array}{c}\text { Mean } \\
\text { ROA }\end{array}$ & $\begin{array}{c}\text { Mean } \\
\text { ROE }\end{array}$ & $\begin{array}{c}\text { ROA } \\
\text { To GDP }\end{array}$ & $\begin{array}{c}\text { ROE } \\
\text { To GDP }\end{array}$ \\
\hline Jordan & 2.3 & 2.6 & 2.7 & 2.8 & 3.1 & 2.7 & 1.21 & 9.74 & 0.45 & 3.61 \\
\hline Palestine & 2.3 & 7.9 & 14.3 & -4.2 & -1.5 & 3.8 & 0.66 & 5.08 & 0.18 & 1.35 \\
\hline Lebanon & 8.0 & 2.0 & 2.2 & 0.9 & 2.0 & 3.0 & 0.92 & 10.69 & 0.30 & 3.54 \\
\hline Iraq & 6.4 & 7.5 & 13.9 & 6.6 & -2.1 & 6.5 & NA & $\mathrm{NA}$ & NA & NA* $^{*}$ \\
\hline Syria & NA & NA & NA & NA & NA & NA & NA & NA & NA & NA \\
\hline & & & & & Ave. & 4.0 & 0.93 & 8.50 & 0.23 & 2.13 \\
\hline
\end{tabular}

Kwan (2006) in his study on Hong Kong banks argue that bank size and inefficiency are positively correlated, due to the different composition of banks' portfolios. However, there was evidence by Staub et al. (2010) in their study on Brazilian banking sector during 2000-2007 that non-performing loans (NPLs), market share, bank size, and bank ownership are an important indicator of banks' efficiency level. Also, they considered NPLs as an important determinant of bank efficiency. However, Abbadi and Abu-Rub (2012) argue that bank loans has no effect on bank efficiency, but ROA and efficiency are highly correlated, and there is a strong correlation between total deposit to total assets ratio.

\subsection{Bank-specific factors and bank efficiency}

Bank-specific factors are considered as an important determinants of bank efficiency in previous literature. Sufian (2009) investigated the efficiency of the Malaysian banking sector around the Asian financial crisis 1997. He indicated that the main determinants of banks' efficiency are a set of bank-specific and macroeconomic variables such as banks' profitability, market share, bank liquidity, bank size, diversification, ownership, and economic conditions. Pasiouras et al. (2009) analysis the banking efficiency into three groups of factors i.e., bank-specific, industry-specific factors, and macroeconomic determinants, and found that a number of internal and external factors have an effect on the efficiency of a bank. Bank-specific factors such as bank size, industry concentration and the investment environment have a positive and significant impact on banks' efficiency (Sufian and Habibullah, 2009). Anbar and Alper (2011) indicated that among the internal bank-specific determinants that affect bank efficiency are bank liquidity, asset quality, and bank size.

However, Vong and Chan (2009) in their study on Macao banks indicated that banking efficiency is more important in affecting bank profitability rather than bank size. Berger et al. (1993) argued that market share has a positive expected correlation with banks' efficiency. Forster and Shaffer (2005) argue that banks' efficiency may generally be considered as a function of both bank-specific characteristics and financial market factors. Furthermore, Growe et al. (2014) investigated the profitability and performance measurements of U.S. regional banks through the period 1994-2011, by applying the efficiency ratio, i.e., (non-interest income over total income). They indicated that the efficiency ratio is a measure of banks' efficiency, and found that there is a significant and negative relationship between profitability and the efficiency ratio.

\subsection{Macroeconomic factors and bank efficiency}

The unstable macroeconomic factors are having a remarkable impact on banks' efficiency. Bos and Kool (2006) indicated that bank efficiency measures can be explained by internal variables capturing the bank's strategic choices, and a group of banking market's variables, as well as macroeconomic variables. Almazari (2014) stated in his study on Saudi and Jordanian banks during 2005-2011 that a selection of internal and external banking characteristics was used to predict profitability and efficiency. Dietrich and Wanzenried (2014) indicated that larger banks might grasp efficiency gains that are reflected in higher earnings because they work in non-competitive financial markets. Moreover, Burki and Niazi (2010) analyzed the effect of financial reforms on bank efficiency of state owned, private owned, and foreign owned banks in Pakistan. Their study on 40 banks in Pakistan during 1991-2000 revealed that there is a positive impact of banks size, interest income to earning assets ratio, and loans to deposit ratio on estimated efficiency scores. Whilst, Petria et al. (2015) in their study of 27 banks in EU region over the period 2004-2011 argue that credit risk, liquidity risk, and banks' management efficiency 
ratio have an influence on bank profitability. Olson and Zoubi (2011) examine the efficiency and profitability of banks in ten Middle East and North Africa (MENA) countries over the period 2000-2008, and found that almost all banks in the MENA region are less cost efficient than European banks, and are below optimal size. Furthermore, Wozniewska (2015) argue that the favorable macroeconomic situation and the increasing scale of banking sector activity have been reflected in the increase of the financial results of banking sector, which affects positively banks' efficiency.

On the other hand, other studies such as Nikiel and Opiela (2002) and Bonin et al. (2005) examined banks' efficiency of the largest banks in six relatively advanced countries, namely, Bulgaria, the Czech Republic, Croatia, Hungary, Poland and Romania, and found that foreign-owned banks are most efficient and government-owned banks are least efficient. However, other previous studies came up with different results. For instance, Girardone et al. (2004) investigated the main determinants of Italian banks' cost efficiency, from the internal banking environment over the period 1993-1996. They found that there is no clear relationship between bank size and bank efficiency. Likewise, other studies such as Jiang et al. (2009) examined the effects of governance changes on bank efficiency in the Chinese banking sector for 11-year period 19952005 , and found that bank efficiency has improved due to the changes in bank governance. In addition, they stated that foreign banking acquisition may benefit domestic banks by gaining more efficiency in the long run.

\section{Conceptual framework and measurements}

The current study's conceptual framework is shown in Fig. 1, a set of bank-specific variables namely: market share, bank liquidity, bank size, and diversification were used as a proxy of banking internal factors. Bank-specific variables are measured in this study as follows: market share is measured by the natural logarithm of deposits
(LNDEPO), bank liquidity is measured by total loans over total assets (TL/TA) and bank size is measured by the natural logarithm of total assets (LNTA). Also, diversification is measured as the ratio of noninterest income to gross income. Vong and Chan (2009) indicated that diversification strategy of a bank can be measured by non-interest income over gross income (NII/GI), and it is an important determinant of efficiency and profitability derived from income statement.

\section{INDEPENDENT VARIABLES}

DEPENDENT VARIABLE

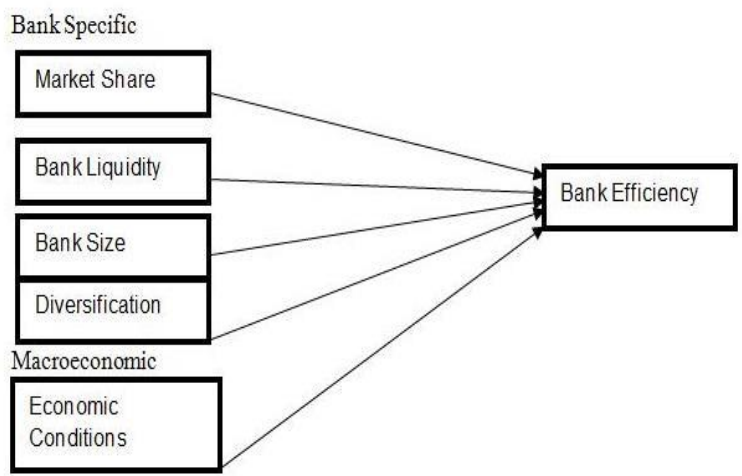

Fig. 1: Proposed conceptual framework

Nevertheless, more diversified banks can generate more income sources which would increase bank efficiency and profitability as well. Also, macroeconomic conditions are proxied by the natural logarithm of GDP (LNGDP) (Sufian, 2009).The dependent variable in this study is bank efficiency (BE) which is measured by bank efficiency ratio (BER). Bank efficiency ratio is measured by the cost-income ratio (Goddard et al., 2010). Hence, the measurement of the cost-income ratio is noninterest expenses over total revenue (NIE/TR), where total revenues are equals to (Non-Interest Income + Net Interest Income) (Forster and Shaffer, 2005; Growe et al., 2014) (Table 2).

\section{Research methodology}

\subsection{Sampling design}

Table 2: Descriptive of the variables used in the regression models

\begin{tabular}{|c|c|c|c|}
\hline Variable & Measure & Notation & Remarks \\
\hline $\begin{array}{l}\text { Dependent Variable: } \\
\text { Bank Efficiency }\end{array}$ & $\begin{array}{l}\text { Non-interest expense over } \\
\text { gross revenues }\end{array}$ & NIE/GR & The efficiency ratio. \\
\hline Market Share & $\begin{array}{l}\text { Natural logarithm of total } \\
\text { deposits }\end{array}$ & LNDEPO & $\begin{array}{c}\text { Is used as a proxy of market } \\
\text { share }\end{array}$ \\
\hline Bank Liquidity & Total loans over total assets & TL/TA & $\begin{array}{l}\text { Is used as an indicator for } \\
\text { bank liquidity position. }\end{array}$ \\
\hline Bank Size & $\begin{array}{l}\text { Natural logarithm of total } \\
\text { assets }\end{array}$ & LNTA & $\begin{array}{l}\text { Is used as a proxy of bank } \\
\text { size }\end{array}$ \\
\hline Diversification & $\begin{array}{l}\text { Non-interest income over } \\
\text { gross revenues }\end{array}$ & NII/GR & $\begin{array}{l}\text { Is used as a proxy of bank } \\
\text { diversification strategy }\end{array}$ \\
\hline Economic Conditions & Natural logarithm of GDP & LNGDP & $\begin{array}{l}\text { Is used as a proxy for } \\
\text { economic conditions }\end{array}$ \\
\hline
\end{tabular}

Our data comprises FCC banks for the period 2005-2014. The balance sheet and income statement data are taken from the Bank scope and
World Bank data; the plan of accounts that all FCC financial institutions have to report to their Central Banks on a yearly basis. Thus, an unbalanced 
banking data from three selected FCC countries namely: Jordan, Lebanon, and Palestine are used in this study, for a ten years period.

\subsection{Research procedure}

To examine the impact of various elements of the selected bank-specific and macroeconomic factors, the multiple regression models are used. Thus, bank efficiency is regressed on the elements of bankspecific and macroeconomic factors. The efficiency ratio(ER) is defined by the US Federal Financial Institutions Examination Council as the ratio of noninterest expense over both non-interest income and net interest income. ER= Non-Interest Expense / Total Revenue (NIE/TR), where total revenue is = Non-Interest Income + Net Interest Income).

\subsection{Hypothesis and regression model}

H1: There is a significant negative relationship between market share and bank efficiency.

$\mathrm{H} 2$ : There is a relationship between total loans to total assets and bank efficiency.

H3: There is a significant negative relationship between bank size and bank efficiency.

H4: There is a significant positive relationship between non-interest income to gross revenues and bank efficiency.
H5: There is a relationship between economic conditions and bank efficiency.

Bank efficiency ratio is often considered as the most prevalent ratio to evaluate a bank's efficiency because it reflects both on balance sheet and off balance sheet operations (Forster and Shaffer, 2005). The general regression panel data model used in this study is as follows:

$$
\begin{array}{r}
\theta i t=\beta 0+\beta 1 \text { LNDEPOit }+\beta 2 \text { TLTAit }+\beta 3 \text { LNT Ait } \\
+\beta 4 \text { NIITAit }+\beta 5 \text { LNGDPit }+\varepsilon i t
\end{array}
$$

where,

$$
\begin{aligned}
& \theta \text { it= The efficiency of bank } I \text { at time } t . \\
& \beta 0=\text { is a constant term (the intercept). } \\
& \text { LNDEPO= Natural logarithm of deposits. } \\
& \text { TLTA = Total loans to total assets. } \\
& \text { LNTA = Natural logarithm of total assets. } \\
& \text { NIITA = Non-interest income to total assets. } \\
& \text { LNGDP = Natural logarithm of GDP. }
\end{aligned}
$$

\begin{tabular}{|c|c|c|c|}
\hline & Mean & Std. Deviation & $\mathrm{N}$ \\
\hline NIETR & 51.07526316 & $1.806166609 \mathrm{E} 1$ & 19 \\
\hline LNDEPO & 4.00329969 & 3.742673474 & 19 \\
\hline TLTA & .52082202 & .212581794 & 19 \\
\hline LNTA & 4.36163283 & 3.786236692 & 19 \\
\hline NIIGR & 27.26684211 & 7.215357120 & 19 \\
\hline LNGDP & 1.50395150 & .854745775 & 19 \\
\hline
\end{tabular}

\section{Data analysis}

Our sample consists of 12 banks from three FCC countries as shown in appendix 1 . They were chosen from Lebanon, Palestine, and Jordan based on the availability of banking data, then the descriptive statistics is done for the whole sample as shown in Table 3.

Table 3: Descriptive statistics for whole study sample

The mean value of the efficiency ratio (NIETR) was 51.07, with a standard deviation of 18.06 which is considered high. However, efficiency ratio is related to bank's total assets. Forster and Shaffer (2005) stated that larger banks may have lower non-

\begin{tabular}{|c|c|c|c|c|c|c|c|c|c|}
\hline Model & R & D Saunre & Adjusted & Std. Error of the & \multicolumn{5}{|c|}{ Change Statistics } \\
\hline Model & $\mathrm{K}$ & K square & R Square & Estimate & R Square Change & F Change & df1 & $\mathrm{df} 2$ & Sig. F Change \\
\hline 1 & $.891^{\mathrm{a}}$ & .794 & .715 & 9.649857928 & .794 & 10.012 & 5 & 13 & .000 \\
\hline
\end{tabular}
interest expenses per dollar of assets, which results in a lower average costs. Whereas, the mean value was the highest for the diversification ratio (i.e., NIIGR), it was 27.266 with a standard deviation of 7.215. This result indicates that the banks in FCC area are depending more on non-interest income in their banking activities (Table 4).

Table 4: Model summary

The $\mathrm{R}$ square is .794 , which means that the independent variables can explains 79.4 percent of banks' efficiency, at a significant level of .000 (significant at the 0.05 level)(Table 5).

\section{Results and discussion}

The correlations and regression statistics results are showed in table 5 . It seems that bank liquidity proxied by total loans to total assets (TLTA) ratio does not influence bank efficiency, and doesn't support the study hypothesis. The insignificant results could be due to the weak relation between bank's liquidity and non-interest expense (NIE). This result indicates that banks excessive lending activities compared to total assets do not increase non-interest expense over time.

While we found that there is a significant negative relationship between bank deposits and efficiency ratio, at a correlation level of -.714, also, bank size (LNTA) was found to be significantly and negatively related to bank efficiency ratio at -.727 correlation level. The effect of bank's diversification strategy on bank efficiency is positive, statistically 
significant, but pretty weak (about 0.272 ). Regarding the economic conditions, we find that LNGDP growth rate has not a statistically significant impact on bank efficiency ratio. In the same vein, Petria et al. (2015) stated that the GDP growth has an expected positive effect on bank profitability. This may be explained by the fact that a high GDP growth ratio affects positively the economic growth and development, which affects profitability rather than cost efficiency in banking sector.

Table 5: Correlations and regression statistics

\begin{tabular}{|c|c|c|c|c|c|c|c|}
\hline & & NIETR & LNDEPO & TLTA & LNTA & NIIGR & LNGDP \\
\hline \multirow{6}{*}{ Pearson Correlation } & NIETR & 1.000 & -.714 & -.241 & -.727 & .272 & .096 \\
\hline & LNDEPO & -.714 & 1.000 & -.272 & 1.000 & .069 & .076 \\
\hline & TLTA & -.241 & -.272 & 1.000 & -.252 & -.448 & .136 \\
\hline & LNTA & $\begin{array}{l}-727 \\
\end{array}$ & 1.000 & -.252 & 1.000 & .054 & .070 \\
\hline & NIIGR & .272 & .069 & -.448 & .054 & 1.000 & .113 \\
\hline & LNGDP & .096 & .076 & .136 & .070 & .113 & 1.000 \\
\hline \multirow{6}{*}{ Sig. (1-tailed) } & NIETR & & .000 & .160 & .000 & .013 & .348 \\
\hline & LNDEPO & .000 & . & .130 & .000 & .389 & .379 \\
\hline & TLTA & .160 & .130 & . & .149 & .027 & .289 \\
\hline & LNTA & .000 & .000 & .149 & . & .414 & .389 \\
\hline & NIIGR & .013 & .389 & .027 & .414 & . & .322 \\
\hline & LNGDP & .348 & .379 & .289 & .389 & .322 & \\
\hline
\end{tabular}

\section{Conclusion}

After analyzing the effect of the main bankspecific and macroeconomic variables on bank efficiency in 12 FCC banks, we can conclude that the empirical findings are almost consistent with the expected results. Thus, market share, bank size, and diversification have an effect on bank efficiency; however, macroeconomic conditions have no impact on bank cost efficiency.

As a policy recommendation for decision makers and authorities, we suggest a better supervision for banking markets and unstable macroeconomic conditions. Also, credit and liquidity risk of banks in the FCC area.

Our recommendation for banks' decision makers is to diversify the sources of revenues and to optimize bank costs, in order to avoid the negative effect of the unstable macroeconomic factors.

\section{Acknowledgements}

I would like to thank my supervisor for her encouragement and her appreciation of my efforts, also her valuable comments that helped me in improving my research experience and techniques. Any remaining errors are, of course, our own.

\section{References}

Abbadi SM and Abu-Rub N (2012). The effect of capital structure on the performance of palestinian financial institutions. British Journal of Economics, Finance and Management Sciences, January, 3(2): 99-100.

Almazari AA (2014). Impact of internal factors on bank profitability: Comparative study between Saudi Arabia and Jordan. Journal of Applied Finance and Banking, 4(1): 125-140.

Anbar A and Alper D (2011). Bank specific and macroeconomic determinants of commercial bank profitability: Empirical evidence from Turkey. Business and Economics Research Journal, 2(2): 139-152.

Ataullah A and Le H (2006). Economic reforms and bank efficiency in developing countries: the case of the Indian banking industry. Applied Financial Economics, 16(9): 653-663.

Berger AN, Hancock D and Humphrey DB (1993). Bank efficiency derived from the profit function. Journal of Banking and Finance, 17(2): 317-347.

Bonin JP, Hasan I and Wachtel P (2005). Privatization matters: Bank efficiency in transition countries. Journal of Banking and Finance, 29(8): 2155-2178.

Bos JW and Kool CJ (2006). Bank efficiency: The role of bank strategy and local market conditions. Journal of Banking and Finance, 30(7): 19531974.

Burki AA and Niazi GSK (2010). Impact of financial reforms on efficiency of state-owned, private and foreign banks in Pakistan. Applied Economics, 42(24): 3147-3160.

Dietrich A and Wanzenried G (2014). The determinants of commercial banking profitability in low-, middle-, and high-income countries. The Quarterly Review of Economics and Finance, 54(3): 337-354.

Forster J and Shaffer S (2005). Bank efficiency ratios in Latin America. Applied Economics Letters, 12(9): 529-532.

García-Herrero A, Gavilá S and Santabárbara D (2009). What explains the low profitability of Chinese banks?. Journal of Banking and Finance, 33(11): 2080-2092.

Girardone C, Molyneux P and Gardener EP (2004). Analysing the determinants of bank efficiency: the case of Italian banks. Applied Economics, 36(3): 215-227. 
Goddard J, Liu H, Molyneux P and Wilson JO (2010). Do bank profits converge?. European Financial Management, 19: 345-365. https://doi.org/ 10.1111/j.1468-036X.2010.00578.x

Growe G, DeBruine M, Lee JY and Tudón Maldonado JF (2014). The profitability and performance measurement of us regional banks using the predictive focus of the "Fundamental Analysis Research". Advances in Management Accounting Emerald Group Publishing Limited, 24: 189-237.

Jiang C, Yao S and Zhang Z (2009). The effects of governance changes on bank efficiency in China: A stochastic distance function approach. China Economic Review, 20(4): 717-731.

Kwan S (2006). The X-efficiency of commercial banks in Hong Kong. Journal of Banking and Finance, 30(4): 1127-1147

Nikiel EM and Opiela TP (2002). Customer type and bank efficiency in Poland: Implications for emerging market banking. Contemporary Economic Policy, 20(3): 255-271.

Olson D and Zoubi TA (2011). Efficiency and bank profitability in MENA countries. Emerging Markets Review, 12(2): 94-110.

Pasiouras F, Delis MD and Papanikolaou NI (2009). Determinants of bank efficiency: evidence from a semi-parametric methodology. Managerial Finance, 35(3): 260-275.
Petria N, Capraru B and Ihnatov I (2015). Determinants of banks' profitability: Evidence from EU 27 Banking Systems. Procedia Economics and Finance, 20: 518-524.

Staub RB, e Souza GDS and Tabak BM (2010). Evolution of bank efficiency in Brazil: A DEA approach. European Journal of Operational Research, 202(1): 204-213.

Sufian F (2009). Determinants of bank efficiency during unstable macroeconomic environment: Empirical evidence from Malaysia. Research in International Business and Finance, 23(1): 54-77.

Sufian F (2012). Determinants of bank profitability in developing economies: empirical evidence from the South Asian banking sectors. Contemporary South Asia, 20(3): 375-399.

Sufian F and Habibullah MS (2009). Bank specific and macroeconomic determinants of bank profitability: Empirical evidence from the China banking sector. Frontiers of Economics in China, 4(2): 274-291.

Vong P and Chan HS (2009). Determinants of bank profitability in Macao. Macau Monetary Research Bulletin, 12(6): 93-113.

Wozniewska G (2015). Methods of measuring the efficiency of commercial banks: an example of Polish banks. Ekonomika, 84: 81-91. 